\title{
On instant pedagogy
}

\section{KEYWORDS}

identity, risk society, instant pedagogy, genealogy of expert cul ture, consumer culture

\begin{abstract}
The main intention of this text is to show the interpretative track in the attempt to find the genealogy of expert appraisal. The main thesis expresses Zygmunt Bauman's view of mutual connection between the weak and light status of identity in consumer culture and the tendency to create cultural practices in order to overcome that weakness, and to strengthen and confirm that status of identity. On the one hand, the main feature of consumer culture and our freedom expressed by consumption determines our identities and is the main reason for "corrosion of identity" (R. Sennett), but on the other hand it demands and generates the necessity of cultural institutions that guarantee its confirmation. Hence, we may find the reason for the so-called "Counselling boom" and expansion of expert appraisal in our risk society. The presented text also shows the cultural background for cultural practices in the risk society and consists of the attempt to grasp social instant pedagogies. This phenomenon is analysed here by the role of advertisements and psychological guides as the main cultural practices of instant pedagogy. My intention seeks to bring to account often hidden and obvious practices, and to highlight in a critical manner the tendencies in our social milieu and in the face of "the unbearable lightness of consumption".
\end{abstract}

Adam Mickiewicz University Press, pp. 95-114

ISSN 2300-0422. DOI 10.14746/kse.2019.15.7

ORCID: https://orcid.org/0000-0003-0681-8295

I would like to cover with the topic of my musings the dense field of cultural practices inseparably tied to the emergence of the contemporary form of exert appraisal. I would like to pursue the question and discoursively shape the complex conglomerate of thoughts delineated by the problem of even the sketch of the cultural genealogy of expert appraisal. The topic described as such suggests many discon- 
nected, sometimes detached connotations. There emerge contemporary fetishes and figures of social discourse as well as the most varied labels formulated by researchers seeking self-definition frames for contemporary culture. In such a broad field of cognitive views as the risk society (U. Beck), therapy culture (J. Baudrillard, M. Jacyno), instant culture (Z. Melosik), post-secular society (Ch. Taylor, J. Mariański), post-humanism, culture of individualism (M. Jacyno), I would like to take a closer look at the categories of risk, identity, life policy, which - I believe - shall provide my attempt with the character of slightly more legitimised statements. Any attempt to embed thoughts on the genealogy of expert appraisal in the space of culture analyses requires, in my view, stressing of the presence of these categories in the context of many legal interpretations and the views of the problem established in discourse. In my undertaking, these categories appear to be binding ones - categories binding significant dimensions of social life and binding many cognitive tropes and interpretation attempts, through these categories, discourse gains an anchor in social practices.

I would like to present the thoughts of Zygmunt Bauman, Polish sociologists, one of the most important thinkers of the recent time, an attentive participant in the phase of the cultural transformation, a the same time a critical analyst of the post-modern world all the way to his latest work, the posthumously published "Retrotopia”. Bauman's analyses aim to disclose the hidden meanings of culture, its deep structure and the grammar of life in the gears of consumer freedom. I believe that the work of Bauman fulfils a significant function in hermeneutic work and attempts at understanding the world to which we have gained access three decades ago. ${ }^{\text {la }}$ We struggled to catch up with the culture of the time of globalisation, and Bauman's work constituted a mature response of a researcher and an active participant of a world, in which disconcerting consumerist phenomena were all too clear. Our situation constituted a cultural and civilisation turning point, and Bauman's reflection disclosed - as I remember in the 1990s - frequently unsettling phenomena in the sphere of morality and ethic, identity or freedom. All the way until his ultimate work, the contact with deep reflection, its critical tone constituted a challenge within attempts to come to terms with phenomena and significant threats to identity in a time of risk, in a liquid phase of culture. It seems to me that the work of Zygmunt Bauman fits perfectly in thoughts encompassed by the title of this paper. Even if they are somewhat belated, I would still like to present one dominant motif of his work and to return to issues of ambiguous identity and freedom

1 The author refers here to the fall of communism and the transformation of 1989 [translator's note]. 
in the context of consumer culture I dealt with in my doctoral thesis (March 2018). I would like to refer to the implications of his thoughts for our understanding of certain phenomena in the area of identity, in order to better understand the condition of the world and the existential effects of life in instant culture.

My presentation aims at indicating a general tension of the culture of consumption in the form of modes of construction of identity in consumer freedom and the unsettlingly weak, light status of identity. This property of it is the cause of a veritable "counselling boom" in culture, a tendency to reinforce identity as a response to the inadequacy of identity. In this context shines through the main practice of instant culture, in the form of guidebook discourse as an indication of reflectively constructed identity. These are phenomena complementing the image of anthropological consequences of the dominant consumer approach of instant culture, which, together with expert psychological appraisal and advertising creates paedagogies and cultural practices that are characteristic of it, in order to counter the tension caused by „the unbearable lightness of consumption". The general intent is to consider selected aspects of consumer culture and to indicate implications for our tendency that Zygmunt Bauman described as „consuming life”.

In contemporary attempts to describe culture, consumption becomes the dominant plane of analysis. In a consumption society, it plays a frontal role in the mode, in which it determines the entirety of our social behaviour. According to many analysts of post-modern culture, consumption fundamentally describes the horizon of our deepest and most fundamental existential choices. Consumption becomes a symbolic plane, through which the post-modern man expresses their irreplaceable identity, it becomes at the same time a significant dimension in the analysis of transformation to which other important societal institutions (e. g. religion or education) are subjected. However, what I would like to stress has in its fundamental systemic and symbolic role also a fact that does not quite fit us. As a plane of expression of the post-modern man, consumption plays the role of the entire universe, entering the daily world of modern people, describing their patterns of participation in social life, however, putting man in a situation of the unfulfilled promise that is included in the consumption dance. It seems as though the property of consumption culture that fluidity, variability, a unique lightness and immediacy of execution definitely are, causes this state of unbearable lightness to become the dominant existential state of the spirit of consumers entwined in the game to provide meanings in modes of dominant consumption. The existential mood indicated above naturally has its unsettling cultural effects - the search for a stable identity (as it will turn out - not to be achieved by consumption), rein- 
forces the cultural need for services guaranteeing it. The response to the lightness seems to be high demand for the provision of expert services in the instant culture - it is the practice of coping with the unbearable lightness... of consumption... that is enshrined in the model of consumer culture.

For several decades, Zygmunt Bauman has been taming post-modern culture for us, bravely disclosing before us its intricacies. In this, he is based on the disclosure of even simple meanings, veritably banal events that make up the cultural praxis of the post-modern man. Identity, freedom, ambiguity, globalisation, poverty - these are the keywords in his diagnosis of the late modern period. Bauman embeds his thorough analyses directly in Disneyland culture. He traces the transformation of personal types as post-modernity heroes. The Flâneur or a loafer along city streets is constantly seduced by institutions of culture to consume goods, the offer of which is unlimited. He looks at processes of establishment of identity using puzzles available on the global market. Identity is nothing else but a collage, a mosaic, shreds of experiences that make up a unique market-based design. He writes that professional work as a design for life is not fulfilled any more in attempts to integrate the axes of biographical narration. Post-modern culture experiences an increase in the value of entertainment, play as forms of participation, and the reversal of the Freudian dyad so typical for us - the rule of pleasure before the rule of reality. The life context is privatised, heightening ambiguity and uncertainty of the ordinary participant in the cultural game of identity.

\section{Identity as an incomplete project}

In his rich body of work, Zygmunt Bauman devoted much space to thorough analyses of identity in post-modern culture. Frequently, it is post-modernity itself as a condition of culture that is defined in the sphere of subjective identity. It is difficult to analyse one without the other. In his work Liquid Modernity (2006) he again took to scientifically analysing the issue of identity and changes in the life context of the inhabitant of the global village. I believe that the thoughts contained within it merit quoting in this sketch, the task of which is primarily bringing to order reflections on identity in the time of globalisation. In Bauman's view, modern culture includes a tendency to "melt” or "dissolve” historic, permanent, solid components that indicated and determined the existential context of man of the recent centuries. In a time of liquid modernity ,we [...] are dealing with an individualised and privatised version of modernity, in which the duty to create patterns and the responsibility for failure rest primarily on the shoulders of individuals" (Bauman 
2006, pp. 14-15)2. This change forces a rethink of the fundamental categories describing the human condition of the time of globalisation. The first fundamental context for thoughts on the identity of a man in modernity is to ponder the fall of all permanent reference systems that in not that distant past gave meaning to human existence. Whereas in present times: „The insufficiency of such patterns, codes and rules that might be adhered to, that might be considered points of reference and by which one could be guided in the future becomes ever clearer now. This does not at all mean that our contemporaries are driven in life solely by their own imagination and creativity, that they create their own methods of living from the ground up and as they please, without using buildings blocks and designs provided by society. This means, however, that we are presently moving from the era of imposed "reference groups" to an era of "common comparisons and lists", in which the ultimate of individual effort of self-creation is, by law and irrevocably, indefinite, unknown and threatened by frequent and deep changes, as their real end is the end of human life" (Bauman 2006, p. 14). Contemporary times have experienced in this regard a radical reformulation in the understanding of identity that must be perceived as an individual life policy, as an individualised strategy of life, as one version of several possible solutions and options to choose from. Bauman writes: „Today, patterns and orders are no longer "given” or for that matter "obvious". There are too many of them; they collide, and their rules oppose each other, stripping them of unconquerable, overpowering force. They have changed their character and started being perceived suitably to this change: as items on an individual to-do list. Instead of preceding the choice of life strategy and describing its future course, they are to be adapted to it (or to stem from it), giving way to its variable and unforeseen influences" (Bauman 2006, p. 14). The individual life design includes ever more strongly uncertainty at the time of self-determination, as too many possible paths co-exist, too many potential options to choose from. As a result, „contemporary changed situation shall see the majority of people cracking their heads through most of their lives rather over choosing the right objectives than looking for means to achieve objectives that give rise to no doubts at all" (Bauman 2006, p. 94). Every life design includes uncertainty and existential necessity to create identity upon one's own expense and responsibility. As Bauman notes: „If possibilities are to remain endless, it cannot be allowed for any one of them to solidify into permanent reality. They should remain liquid and fleeting, provided with a usable shelf life so that they do not hinder access to other possibilities and stifle future adventures" (Bauman 2006, p. 96). Life designs, co carefully

\footnotetext{
2 All quotes (re)translated into English by the translator of the article into English.
} 
constructed in post-modern culture, are characterised by the status of incomplete determination and non-finality. Bauman writes: „The state of non-finality, incompleteness and indetermination is related to the experience of risk and disquiet, but its opposition also does not provide the feeling of unruffled joy, as it closes possibilities that, in the name of freedom, should remain open" (Bauman 2006, p. 96). The archetype of this mad race after a new pattern, a new variant of identity, is the post-modern model of consumption. As Bauman describes it: „In a consumption society, giving into the consumption addition - the ubiquitous shopaholism - is the sine qua non condition of all individual freedom, primarily the right to difference, to "having an identity"'(Bauman 2006, p. 129). A property of identity achieved in such a way is its volatility and fleetingness, which facilitates the tendency to look on the market for ever newer models and to abandon old ones the moment subsequent choices are made. The entire nightmare and paradox of identity-related activity in our time is for ,identity” - being „unique" and „one-ofa-kind" - [...] to be constructed exclusively out of those materials that are selected and bought by everyone" (Bauman 2006, p. 130). Zygmunt Bauman proves in his work Freedom that in contemporary time to construct an identity means to select from among the goods offered on the market (consumption), symbols of identity. These symbols are so numerous that infinite combinations and arrangements are possible, everybody creates a unique design, a market mosaic. The market offers us contemporaneously so many possibilities, together with the freedom to choose and unlimited self-creation. This creates the need of the competence of flexibly following the emerging changes of the market offer. Bauman describes this as follows: „In a world, in which purposefully fleeting items form the foundation of identity - also fleeting, by necessity - one must remain constantly vigilant, but primarily ensure flexibility and care for the ability to quickly adapt to the new conditions so as to follow the changing shape of the "outside" world” (Bauman 2006, p. 130). The multitude of possibilities to create identity facilitates attitudes of the loose, indeterminate status of identity achieved in this way. As Bauman remarks: „What counts is how people themselves experience, receive and live this arranged necessity to construct and reconstruct identity. In contemporary consumption society, such phenomena as the loose, „associative" status of identity, the ability to "purchase', pick and abandon one's "true self” and the possibility of "being in motion" have become hallmarks of freedom, and irrespective of whether the analyst deems them to be real or illusive" (Bauman 2006, p. 135). It seems that Melosik and Szkudlarek aptly describe the paradoxes of post-modern identity policy: „Perhaps under the guise of freedom (or more precisely, the reduction of freedom to one of its socially constructed forms - the freedom to buy) we are dealing with subtle and blissful 
control of identity? [...] The consumerist ideology includes the category of permanent inadequacy of the identity of the consumer, the category of non-fulfilment or rather incomplete fulfilment. One would believe that they have almost reached the basic raw state of their identity - that they have become what they should be (of course, thanks to appropriately prestigious or fascinating shopping). A moment later, however, they feel that the moment of satisfaction is gone, never to return, and hence the hunt must begin anew. As a result, man lives in constant consumerist disquiet that becomes their normal condition" (Melosik, Szkudlarek 2009, p. 32). In this way, we touch upon this unbearable lightness of identity as the effect of the immanent lightness of consumption.

To conclude this part on the modes of construction of the post-modern identity I would like to propose a psychological reading of the work of Zygmunt Bauman, in particular his approach to the „ambiguous identity” and the meaning of the existential need of "expert psychological appraisal” as a "reducer of ambiguity" and "inadequacy" of the market identity, offered in the seasonal and volatile consumption of goods. Culture as a "consumer cooperative” is characterised by high variability of the market offer, of which every participant in social life must pick their own set of "significant symbols” as the building blocks of identity, and the situation of overproduction of goods and meanings strips this choice of correctness and suitability. This in turn creates a broad field of existential uncertainty (ambiguity) caused, as Bauman states, by the „privatisation of existence" or the dissolution of all forms of interpersonal relations. Post-modern culture is the disappearance of all fixed reference systems, permanent foundations, subjective identity caused mainly by the lack of certainty in the instance of self-creation and the creation of one's own template or the establishment of identity as a "market-based puzzle". Bauman writes straight up about the drama of inadequacy of identity of the inhabitant in the global village, creating the need of an „expert psychological appraisal”. The inadequacy of the post-modern identity is the cause for searching of certainty and reduction of ambiguity that can only be provided by EXPERT APPRAISAL as a rubber stamp of normality or lay confirmation. The need for psychological expert appraisal continues to gain momentum, and the dissolution of psychological discourse and therapeutical practices to many schools and orientations only reinforces existential ambiguity. As Bauman notes, it also stresses the exclusively conditional efficacy of all kinds of life advice produced by advisors or guidebooks. He writes: „Recipes for a happy life and tools needed to achieve them have a "best-by date", but most of them is out of use much earlier, eclipsed, depreciated and stripped of charm by competing "new, even better" offers"(Bauman 2006, p. 112). 
This is the way the internal tension of consumption culture takes shape. Fragile identity needs support, and this need is filled by a broad range of services, advice or therapy being at the same time the field of a veritable counselling boom. Borne out of the need to anchor incomplete, frail identity designs, the practice of social confirmation of an insufficient and fleeting identity are two ends of the same phenomenon. It turns out that an identity constructed in such a way in the machine of consumption, is characterised by lightness, and the spiritual state brought about by this unbearable lightness should be treated as a sign of losses coexisting with consumption, described by Zygmunt Bauman in his work Consuming Life.

\section{The risk society}

According to A. Giddens, in late modernity, in the post-traditional society, „personal identity, as well as the broad institutional context, must be created with reflection"(Giddens 2006, p. 34). According to U. Beck, contemporary society can be described as a risk society. In risk society, ,everything undergoes constant change, and our thinking of the future runs along many alternative scenarios. Risk refers to purposeful activity of man, to rational choices under conditions of uncertainty, but even so, all human life may be burdened by risk that is, in a sense, external" (Beck 2009, p. 35). As A. Giddens puts it: „Modernity reduces the overall riskiness of certain spheres and modes of living, at the same time introducing new parameters of risk that were almost or completely unknown to previous times. [...] The late-modern world is apocalyptic but not because it inexorably moves towards a catastrophe, but because it brings with it such forms of risk that were unknown to past generations” (Giddens 2006, p. 7). U. Beck states in turn: „Individuals must to an ever greater extent themselves see, interpret and manage possibilities, threats and ambiguities emerging in their lives, with which they coped earlier in the family circle, in the local community or by reference to a social class or group. [...] Even the „own self” loses its historic clarity and is subdivided into opposing discourses"(Beck 2009, p. 20).

In the opinion of Piotr Sztompka, risk in the subjective dimension is characterised by: „1. Stronger sensitivity to threats and danger stemming from the reduction of the role of defence mechanisms and magical as well as religious rationalisation; 2. Ever more common awareness of threats due to continuously improving education levels; 3 . Ever later occurring clarity as to the imperfections in expert knowledge and repeating errors in the functioning of abstract systems. All this leads to the establishment of a specific non-clarity, uncertainty and the fluid char- 
acter of social life under conditions of late modernity" (Sztompka 2005, pp. 91-92). We now let A. Giddens speak: „The problem, I repeat, is not that life has in itself become more risky than in times past. The case is that in conditions of modernity, thinking in categories of risk and risk assessment is quite frankly a task that constantly, yet perhaps unnoticeably, both laymen as well as experts are continuously at" (Giddens 2006, p. 170).

In the view of Małgorzata Jacyno, the globalisation of risk, meaning, the objective dimensions of risk, are „accompanied by transfer of responsibility: not weakening state authorities but individuals are bestowed with the task of choosing and applying efficient preventive measures both in terms of civilisation diseases, the ozone hole, terrorist attacks as well as marital infidelity and unemployment" (Jacyno 2007, p. 170). According to Jacyno, risk „is the semantic horizon of the human experience" and "describes the essence or the other side, a more or less hidden sense of what individuals experience" (Jacyno 2007, p. 93). In her view, two strategies of coping with risk are possible: first of all - „attempts at rational control and handling risk”; second - „attempts at rejecting the sense of experience closed in risk and prevention" (Jacyno 2007, p. 92). The first risk-coping strategy refers to expert appraisal, which, according to Giddens, replaces tradition in post-modern society. The second strategy entails a temporary suspension of risk, which boils down to the attitude of choosing risk as a form of controlling it, because it is chosen as my fate, as the destiny. As Jacyno writes, „suicidal and semi-suicidal practices (illegal car racing, extreme sports, survival camps or searching via newspaper classifieds for a partner who would guarantee a HIV infection) are attempts at returning to a traditional world, in which the individual is „rescued” by its destiny, not prevention" (Jacyno 2007, p. 92).

I suggest considering the concept of the culture of liquid modernity, expressed by Zygmunt Bauman, through the category of uncertainty as suggested by Sławomir Kmiecikowski in his work Uncertainty - Zygmunt Bauman's Basic Ethical-Anthropological Category. As the author notes, Bauman's reflection is overarched by the category of uncertainty, present in his analyses of post-modern ethics, in anthropological thinking on the identity of the post-modern period, and it is furthermore implicite contained in Bauman's work concerning the ontological status of the liquid modernity society. In the author's view, „uncertainty turns out to be an immanent, significant moment of existence of the contemporary individual that cannot be isolated from the global whole any more; a whole that exerts influence on the existence of an individual, and remains under it" (Kmiecikowski 2011, p. 39). According to Bauman, significance and the expansion of thinking about on identity in the culture of the end of the 20th century is caused by the fact that 
„identity had become the prism through which significant aspects of contemporary life are viewed, understood and studied" (Bauman 2008, p. 71). In Bauman's view, identity generates the fundamental link of the culture of liquid modernity, meaning, the inadequacy of the market patchwork caused by privatisation and deregulation processes. Bauman writes about the consumption syndrome that is „an approach to practically all components of social space and the actions initiated and shaped by it" (Bauman 2007, p. 130).

The consumption syndrome is - according to Bauman - a ,set of diverse yet closely related stances and strategies, cognitive attitudes, value judgements, presuppositions, clearly formulated and silently made assumptions on the rules governing the world" (Bauman 2007, p. 81). According to S. Kmiecikowski, subjective reality reduced to the mode of being the consumer, and - what must be stressed its exhaustive nature that colonises identity discourse to become subjective market fetishism causes humanity to „on the one hand be blended into external uncertainty $[\ldots]$, yet on the other hand, this humanity seems to be subject to influences of this uncertainty. In other words - the uncertainty transcendental with respect to the subject seems to permeate human nature to its core" (Kmiecikowski 2011, p. 81). As Bauman writes: „What is considered to be the manifestation of the inner truth of a subject is in actuality the idealisation of material - objectified - traces of consumer decisions" (Bauman 2009, p. 21). In his work Liquid Life (2007), Bauman, characterising the identity of the liquid modernity culture, noted that the sole descriptor of man is homo eligens (man choosing), and identity is characterised by non-fulfilment, non-finity and non-authenticity. In the consumption society, subjectiveness expressed by transactions of purchase and sale of symbols to create identity ,is in essence a "simulacrum” as understood by Jean Baudrillard, putting a "representation" in place of what it is supposed to represent, and what must be removed from the final form of the product" (Bauman 2009, p. 21).

Kmiecikowski notes that uncertainty constitutes a category that is ever-present in Bauman's reflection that is used by him in course of ethical and anthropological musings; it can also describe the ontological status of the world of the time of liquid modernity. In Bauman's analyses, one can find the conviction of the chaotic, ambiguous and liquid reality. In view of Kmiecikowski, it is reality that „pulsates with instability and variability, and the uncertainty and helplessness of the contemporary man only constitutes a unique exemplification of existential ambiguity and opposition" (Kmiecikowski 2011, p. 91).

In view of Kmiecikowski, thoughts on identity in a time of liquid modernity [give rise] to the conviction about uncertainty being transcendental as compared to man, and a discernible intuition that "the outside world pulsates with varia- 
bility and prevents man from cognitively touching upon existential rationality" (Kmiecikowski 2011, p. 83).

Bauman summarises his analyses of identity this way: „Instead of one, one must cope with several patterns in post-modernity - however, not in order to recreate the diversity of modes appropriately selected to suit personal or group preference, but in order to show the internal discontinuity of the mode, to which all people and each of them separately are party under post-modern conditions. The multitude of types indicates the analytical "impurity” of being, its incoherence, lability, chronic ambiguity, inconsequence" (Bauman 1994, p. 21).

In Bauman's view, this leads to the condition, whereby „we are dealing today with an individualised and privatised version of modernity, in which the duty to create patterns and the responsibility for failure rest primarily on the shoulders of individuals" (Bauman 2007, pp. 14-15). Tomasz Kunz summarises the work of Zygmunt Bauman in his work Zygmunt Bauman pochwała niepewności albo socjologia jako wyzwanie moralne [Zygmunt Bauman, a praise of uncertainty or sociology as a moral challenge]: „Ambiguity and liquidity of the modern world, in which it is impossible to find support in durable and repeatable cultural patterns, stable and recognisable identities, fixed ethical codes, clear social distinctions and hierarchies, subjects the individual to uncertainty that since becomes an inseparable partner in their lives" (Kunz 2013).

\section{The birth of the culture of experts}

In searching for a stable identity, its ,anchor", in a world of sudden global acceleration, in a world of busted myths and fallen authorities, caused by the inadequacy of identity built on loose soil of ",market competition over status indicators and symbols", over a difference, it facilitates all tendencies to stifle and reduce precisely ambiguity and at the same time creates the need of „expert appraisal" as a rubber stamp of normality and guarantee of social approval. As Bauman noted: „It is a paradox (or perhaps it isn't one at all) that the privatisation of ambiguity invigorates and expands the development of public expertise and a thick network of public specialists in solving private problems” (Bauman 1994, p. 228). The search for an „expert opinion" creates the opportunity of establishment of a culture of experts, authorities on the limits of normality and social perversion, mental health or even good taste. The "appraisal" should also not be treated exclusively as a social service on the service market, but also as an "existential reducer" of ambiguity and the feeling of inadequacy of subjective identity as inexorably described in the life of man in a time after all 
meta-narrations have fallen and common sense decayed. In Bauman's view: „From the point of view of the user, an expert appraisal provides socially accepted modes of solving personal problems, naming them beforehand, and with equal authority, as problems requiring corrective measures. [...] The expert appraisal thus enters personal life at quite an early stage, when unclear and unfocused fears and anxieties stemming from uncertainty and ambiguity of experiences or feelings are articulated in the social language as individual problems requiring the usage or supra-individual („objective”) solutions” (Bauman 1994, p. 230).

In this way, the market paedagogy of post-modernity takes over all such solutions of the issue of reduction of identity ambiguity. The demand for "appraisals” and the omnipresent global market causes the specialisation of certain groups or individuals in the provision of such services. This role is played in post-modern culture by psychological guides, as a further example of instant paedagogy. Every one of such guidebooks contains solutions to existentially significant aspects of life searching to be rescued in a world devoid of convincing internal solutions. In instant culture, everything is available now and in unlimited volumes. Everything has become a commodity. Even issues of subjective identity in post-modern culture are solved in the mentioned „market game”.

Culture - in Bauman's perspective - is a "consumer cooperative” characterised by significant variability of the market offer, and from which every participant of social life must pick their own set of "significant symbols” as the building blocks to create their own identity, and the situation of overproduction of goods and meanings strips this choice of correctness and adequacy. This in turn creates an enormous field of existential uncertainty (ambiguity) caused, as Bauman says, by the "privatisation of existence" or the decay of all forms of interpersonal relations. Post-modern culture is the decay of all permanent reference systems, fixed foundations of subjective identity caused mainly by the lack of certainty in the moment of self-creation and the creation of one's own pattern, or creating identity as a "market-based puzzle”. As M. Lewartowska-Zychowicz writes: „Consumption requires particular competences and knowledge that are supplied by media experts, sponsored authorities and statistics. Their role seemingly entails limiting uncertainty related to the freedom to choose, however in actuality it means control over cognitive habits and knowledge of the people, meaning, actual governance of their identity" (Lewartowska-Zychowicz 2010, p. 246). As Bauman notes, stressed is also the barely conditional efficacy of all life advice produced by advisors or guidebooks.

In view of M. Lewartowska-Zychowicz, since culture was dominated by the discoursive politics of capital, changes also touch upon the policy of identity in the cradle of consumption culture, as a result of which "the consumption dur- 
ing development of the homogeneous attitude of identification and focusing the identity development process leading to the establishment of commodified and uniformised identities - which in essence are functional as compared to consumer freedom” (Lewartowska-Zychowicz 2010, p. 247). This also means that "hence, economic processes not only determine man's mode of living, but also process the structure of their character in such a way so that it would maintain the status quo" (Lewartowska-Zychowicz 2010, p. 250).

At this point, I would like to collate the analyses of Edyta Zierkiewicz on guidebook language and the rhetoric of advice discourse and the used persuasion tools that appear in guides. In this regard, important is the assumption that „the structure of a guidebook text should remind of the process of provision of help in direct counselling" (Zierkiewicz 2004, p. 62). Important is also the assumption that „a guidebook's message is a specific form of linguistic influence, in which the individual components reinforce its didactic and persuasive character. Such significant aspects may include: statement style, lexical colloquialism, strategies of reaching an agreement with the reader, its didacticism and dialogue" (Zierkiewicz 2004, p. 64). The analyses of Edyta Zierkiewicz in the work Poradnik. Oferta wirtualnej pomocy? [The Guidebook. An offer of virtual help?] are for me the fundamental source of knowledge on the used tools of persuasion in guidebook discourse language. Polish researchers of guidebook discourse also include Małgorzata Jacyno and her work in the genealogy of therapeutic culture.

The style of guidebook discourse bears the following characteristics:

- it is informal, personal and living, direct, material, clear, specific, understandable to the average reader;

- colloquialisms (stimulating the existence of a direct relation between sender and recipient in it);

- didacticism (the core is to influence the reader; it is more or less a quintessence of direct influence, dominated by such communication forms as: encouraging, convincing, argumenting);

- intentional establishment of a relationship of closeness between the author and the reader (so-called closeness achievement strategies); (orientation towards subjectivism and value judgement" (Zierkiewicz 2004, pp. 65-66). The author exhaustively lists typical rhetorical tools used in guidebook discourse, however, it must be stressed that "guidebooks are a particular type of written material permeated by persuasion" (Zierkiewicz 2004, p. 147). In my opinion, however, the utilised resources should be enumerated so as to get an idea of the style of work of the virtual advisor or therapist. The author lists the following resources used in guidebooks: 
- examples and anecdotes (examples describe and present certain characteristic events, specific people, their behaviour and specific situations; the goal is to attract the reader's attention to behaviour considered required or to present an anti-hero, whose actions are evaluated negatively, whose behaviour should not be imitated by the reader);

- metaphor - refers to daily experiences; helps advisors speak about things and problems that cannot yet be described by specialised concepts and vernacular; they are concise, relevant and easy-to-understand phrases that create images or expressions of the subject of discourse);

- aphorisms - provide content in a very general manner, they are like sayings that the reader should internalise and continue repeating; guidebook authors frequently use them as mottos containing wisdom and knowledge; authors translate and explain to readers the sense of such aphorisms, and write out recommendations in informal language;

- visualisation techniques - they entail imagining specific objects, situations, own reactions and behaviour (Zierkiewicz 2004, pp. 139-144).

Edyta Zierkiewicz showcases in the presented paper also a classification of forms of communication between the author-advisor and the reader seeking advice; she lists:

- the sermon - found rarely, not the typical form in contemporary guidebooks;

- persuasion - its object being to exercise influence on the reader seeking advice; it refers to all communication actions aimed at the other that are in place to bring about in them the internal state called a conviction; includes value judgements, as it entails convincing the interlocutor to the self, to the attitude, state or value described by the partner providing advice; the following forms of persuasion can be delineated between:

- convincing persuasion - assumes that the recipient is an intellectually active individual, and that the sender has just intentions and plans;

- encouraging persuasion - clear or hidden, just or unjust; the objective is to convince as many followers as possible to a specific idea or doctrine;

- stimulating persuasion - campaigning; the goal is to win over the recipient for a cause, idea or thought, whereby significant here is immediate, temporary influence based on authoritarian and suggestive conviction.

Guidebooks - this form of instant psychology is, as I wrote in the beginning, a contemporary phenomenon: „In such guidebooks, authors strive to convince the reader, to encourage them to change their attitude that they had up to that point or even to alter their hierarchy of values; sometimes they also want the recipient to 
accept the patterns and objectives as if they were their own, they encourage him to do justice to them. Such a mode of influencing people is characteristic for diverse supporting, help or therapeutic work" (Zierkiewicz 2004, p. 147).

What had happened to the man of the West of the end of the 20th century that they lost the faith in independently handling their own problems, especially mental (including psychological) ones? What took place in the last fifty years that diverse specialists and authorities on psychological matters emerged? The process of living through authorities is progressing (intermediation of one's existence using a source of spiritual wisdom), at the same time, the model of direct contact with oneself is vanishing. This is where room is found for instant psychology to grow, for all kinds of ready psychological recipes and guidebooks.

As Zygmunt Bauman noted, the post-modern period with its typical inflammation of the issue of identity that is hidden in the market game, in the feeling of inadequacy of identity that bothers participants of social life, is an era of the rise of counselling. As he noted, the post-modern period, with the phenomenon of the counselling boom, is an era of specialists in identity problems.

\section{On instant paedagogy}

In this part of the article I wish to show the inexorable process of expansion of cultural practices of instant paedagogy as a response to the contemporaneously changing existential context of the late modern man. Instant paedagogy shall be considered the response to the need to independently construct subjective identities that emerged in Western culture. The social usability and inevitability that is part of instant paedagogy is based on changes in the understanding of process of self-construction of identity designs in the post-modern period.

The main educational practice in post-modern culture are processes of creation of identity. At the same time, suggested was a wholly revolutional approach to the process of creation or acquisition of identity itself. Unique is specifically the understanding of the process of creation of identity, being entirely different from modern interpretation. The post-modern theory of education lets go of the model of educational reflection that was dominant over the last centuries. It is not just „shaping the mind" or „exercising the mind" that defines educational practices, but reference to phenomena from so-called popular culture, in which senses are praised, and its use as the main identity-creating potential defines the post-modern educational practices. My analysis shall begin with the conviction that all social institutions and practices related to the notion of development and the shaping 
of identity are paedagogical in essence. This conviction is founded on the Polish paedagogical thought from the initial period of Transformation, reaching all the way to the beginnings of application of traditional critical paedagogy in Poland. This conviction is also based on the assumption of a relation between the cultural placement of the researcher and processes of creation of identity in critical interpretation of social discourse and critical analysis of discourse. It is my aim to cover the broad social field and social instances, cultural and social institutions of paedagogy that shape the identities of actors of the world in the risk society, in instant culture, in the culture of individualism and in the self-realisation society, in therapeutic culture. And in line with Małgorzata Lewartowska-Zychowicz we may assume that „all social practices and institutions that co-shape identities must be treated as immanently discoursive" (Lewartowska-Zychowicz 2010, p. 20).

\section{Instant paedagogy}

Both the frail identity described by Bauman that is the result of a market game of constant consumption, as well as the negative consequences of late capitalism in the sphere of creation of identity strictly taken constitute the basis for the establishment of a therapeutic society, to use a term from analysts of postmodern culture, Jean Baudrillard (2006) and Małgorzata Jacyno (2007). The process of creation of the post-modern identity - as Bauman (1994) convincingly describes it in his work Modernity and ambivalence - is dominated inseparably by mechanisms of market instant paedagogy, the social practice created in the culture of privatised ambivalence of using the paedagogy of ready-to-use life recipes. Postmodern culture voices particular needs of all kinds of life authorities, and this is the direction taken (along with social demand) by cultural institutions guaranteeing such services, providing tested advice and recipes to build happy lives, equipped with guarantees and certainty; as Anthony Giddens writes "marketed can be (...) the design of identity itself. Not only the lifestyle, but self-realisation can be packaged and distributed in line with market rules" (Giddens 2006, p. 271). In post-modern culture, this need is satisfied by psychological guides responding to diverse needs of the mass reader, colourful magazines pretending to create models to be followed, and of course, television advertising as the dominant social practice of instant paedagogy. Therein lies the source for the subdivision of authorities (trainers, therapists, etc.). These lay priests remain convinced that they found the Holy Grail! Postmodern culture - as proven by the existential need of expert services - is thoroughly controlled by practices of 
instant paedagogy. The discourse of guidebooks or psychological counselling is the main plane of presentation of instant culture.

Instant paedagogy is hence the response of culture to changes in the cultural and existential context of our time; it also has a suitably prepared environment of social acceptance and consent to its practices. Rising existential uncertainty of a player in the societal game of identity and the consumer character of participation in cultural exchange are inseparable causes of the emergence of contemporary education practices in the form of instant paedagogy. Instant paedagogy thus fulfils the significant role of a social stabiliser for subjective identities meticulously constructed in the market game. Nothing would indicate that these types of education practices were to lose their unifying and therapeutical social function. It is presently known, indeed, that advertising fulfils the fundamental informative and persuasive role in the market game of choosing symbolic components to construct frail identities in our times. It similarly seems that the need for psychological guidebooks as well as the advice and hints on the private aspects of identity of the inhabitants of the postmodern world contained in them is not weakening.

In my view, it is thus worthwhile to take a look at postmodern culture from the point of view of the education practices contained within it. Even if in fact when we are immersed in advertising and overly hastily accept the phenomenon of educational practices embedded in advertising, this does not exclude that we can treat it as permanent instant paedagogy in itself. In the consumption society, it is advertising, perhaps save for psychological guidebooks, that is the most frequently used strategy and tool to construct identities, a strategy to keep up with the time, to be trendy and not lose one's chance to participate in the ever-changing offer of market goods and visual symbols. It is through them that we create our identity, a design that is never complete.

In a world, in which the key struggle for identity was shifted towards a struggle for symbols, visual symbols of status, prestige and success, advertising becomes the key ordering tool in a deluge of goods and market services of persuasion. In the consumption society, advertising becomes a form of education, and the game is about the possibility of accessing the main carrier of consumer identity, about symbols (goods and the possibility of satisfying the ever so exorbitant needs). A significant transformation, thanks to which the influence of advertising is so visible, is doubtless the necessity of self-creation inscribed in the mechanism of individual consumption - self-creation, which by the way finds its satisfaction through consumption. This is where the demand of instant culture originates to delay the moment of completion of the search for the fulfilled identity. That is why it is sometimes called the culture of moratorium. As Marek Krajewski writes: 
„The culture of the media society must be a culture of moratorium. The culture of moratorium is the culture of suspension and uncertainty, and in this sense it is a negative continuation of modern culture. It is a culture conscious of itself, of its limitations and consequences, hence, a culture whose cultural character was proven to it. The discovery of the lack of the centre of certainty is accompanied by doubt in the possibility of finding it and by manufacture, mainly by mass media, of a countless volume of its momentary substitutes. The media, taking over the role of main producer and distributor of culture, do not only shape the current life styles, fashions, value systems and objects of faith, but must also, according to their logic, simultaneously destroy them and suggest new ones. Hence, they banish individuals to uncertainty and manufacture a strong desire to overcome it" (Krajewski 1999, p. 79).

As Marek Krajewski stresses, a constant property of advertising is the insntruction manual contained within it; in the world created by it. He writes thus: "The advertising message would thus be an instruction manual for the world that is created within it. The key aspect of every manual is to equip its reader with the ability to control that sphere of life or that device, to which the manual applies" (Krajewski 1999, pp. 74-75).

In this context one finds similarly the function of advertising and its message. Anna Kowal-Orczykowska describes the concept of the message as its involved content, thus:, $[\ldots]$ contemporary message discourse is a new context in the perception and definition of ourselves in the world. It is the path of transmission of specific ideas that seek to pretend to be objective and unquestionable" (Kowal-Orczykowska 2006, p. 112). As Zbyszko Melosik observed: „Advertising is always a veritable recipe for what women should look like and how one should look at them, what kind of mood they should be in and what kind of behaviour is expected of them. Adverts simply contain the essence of the currently valid feminine identity" (Melosik 2010, p. 32). Hence, we should forget advertising as an innocent message as, through its ubiquity, it holds a strong cultural authority on judging what is valid in any given moment. By their omnipresence in the media, it has become a powerful educational force and cultural practice, slowly replacing institutions usually destined to perform these roles. Advertising thus is, in its every form, a further type of instant paedagogy, and its area of influence touches upon mechanisms of construction in the period of the instant. Giddens notes, on late modern conditions, that ,identity narration as part of a reflective project is by design-- frail. To forgo a specific identity may mean to obtain specific mental advantages, but it is certainly also a burden. The individual is forced to create by itself and reconstruct its identity due to altered experiences of everyday life and 
the tendency of modern institutions to fragment the identity of the individual" (Giddens 2006, p. 274).

In this way, the market paedagogy of post-modernity takes over all such solutions of the issue of reduction of ambiguity of identity. The demand for „expert appraisal" and the omnipotent global market cause the specialisation of certain groups or individuals in the provision of such services. This role in postmodern culture is also taken by psychological guidebooks as a further example of instant paedagogy. Each such guidebook contains solutions to existentially significant aspects of life of those searching for salvation for themselves in a world devoid of its own convincing solutions. In instant culture, everything is available, right away and in unlimited volumes. Everything has become a commodity. Issues of the subjective identity in postmodern culture are also solved in the mentioned „market game".

I have attempted to show the social contexts of the process of construction of identity in the period of the instant, and the cultural effects in the form of crystallisation of instant paedagogy that follow, with instant paedagogy being a response to the cultural phenomenon of the lack of anchoring of the meticulously constructed identity. I have described processes found in the general trend of the period of the instant, in which processes of creation of identity determine consumption practices.

\section{Bibliography}

Barker Ch, (2005), Studia kulturowe. Teoria i praktyka, Kraków: Wydawnictwo Uniwersytetu Jagielońskiego.

Baudrillard J. (1998), Precesja symulakrów, [in:] Postmodernizm. Antologia przekładów, R. Nycz (ed.), Kraków.

Baudrillard J., (2006), Społeczeństwo konsumpcyjne. Jego mity i struktury, Warszawa: Sic!

Bauer W., (2006), Tożsamość i przemiany społeczne: przegląd teoretycznych stanowisk, „Teraźniejszość-Człowiek-Edukacja”, no. 4.

Bauman Z., (1994), Nowoczesność wieloznaczna. Wieloznaczność nowoczesna, Warszawa: PWN.

Bauman Z., (2000), Ponowoczesność jako źródło cierpień, Warszawa: Sic!

Bauman Z., (2006), Płynna nowoczesność, Kraków: Wydawnictwo Literackie.

Bauman Z., (2007), Płynne życie. Warszawa.

Bauman Z., (2007), Szanse etyki w zglobalizowanym świecie, Kraków.

Bauman Z., (1995), Wolność, Kraków: Wydawnictwo „Znak”.

Bauman, Z.(2009), Konsumowanie życia, Kraków: Wydawnictwo Uniwersytetu Jagielońskiego.

Beck, U. (2004), Społeczeństwo ryzyka. W drodze do innej nowoczesności, Warszawa: Wydawnictwo Naukowe „Scholar”.

Bogunia-Borowska M., (2006), Ekstremalne metamorfozy-projekt idealnego człowieka i perfekcyjnego życia w ponowoczesnym świecie, „Kultura i Społeczeństwo”, no. 4. 
Bruner, J.(2006), Kultura edukacji, Kraków: Universitas.

Elliot A., (2007), Koncepcje ,ja”, Warszawa: Sic!

Frankl V., (2010), Wola sensu. Założenia i zastosowanie logoterapii, Warszawa: Wydawnictwo „Czarna Owca".

Giddens A., (2006), Nowoczesność i tożsamość. „Ja” i społeczeństwo w epoce późnej nowoczesności, Warszawa: PWN.

Glass, L. (2010), Toksyczni ludzie, Poznań.

Gromkowska A., (2000), Kobieta epoki wiktoriańskiej: społeczne konstruowanie ciała i tożsamości, „Teraźniejszość-Człowiek-Edukacja”, no. 4.

Jacyno, M. (2007), Kultura indywidualizmu, Warszawa: PWN.

Kowal-Orczykowska A., (2007), W niewoli reklamy? Percepcja ukrytych znaczeń reklamy prasowej, Kraków: Oficyna Wydawnicza „Impuls”.

Krajewski M., (1999), Medialna kultura moratorium. Nowoczesność i tradycja w polskich reklamach telewizyjnych, „Kultura i Społeczeństwo”, year XLIII, no. 3.

Lewartowska -Zychowicz M., (2010), Homo liberalis. Od emancypacji do funkcjonalności, Kraków: Oficyna Wydawnicza „Impuls”.

Melosik Z., Szkudlarek T., (2009), Kultura, tożsamość i edukacja. Migotanie znaczeń, Kraków: Oficyna Wydawnicza „Impuls”.

Melosik Z., (2010), Tożsamość, ciało i władza w kulturze instant, Kraków.

Potulicka E., (2010), Pytania o skutki neoliberalnej kultury i edukacji-aspekt jednostkowy i społeczny, Gdańsk: „ARS EDUCANDI”, vol. VII.

Sennett R., (2006), Korozja charakteru. Osobiste konsekwencje pracy w nowym kapitalizmie, Warszawa: Wydawnictwo „MUZA”.

Sennett R., (2010), Kultura nowego kapitalizmu, Warszawa: Wydawnictwo „MUZA”.

Skóra M., (2011), Strategia flexiurity a powstanie kategorii prekariatu, „Nauki Społeczne” no. 2.

Smith, P. (1999), Drawing New Maps: A Radical Cartography of Developmental Disabilities, „Review of Educational Research", vol. 69, no. 2.

Sontag, S. (1999), Choroba jako metafora, Lublin.

Tańczuk R., (1998), Współczesne kłopoty z „tożsamością, „Teraźniejszość-Człowiek-Edukacja”, no. 1. Zierkiewicz, E. (2001), Jaka płeć ma poradnikowy dyskurs?, „Teraźniejszość-Człowiek-Edukacja”, no. 1. Zierkiewicz E. (2004). Poradnik-oferta wirtualnej pomocy?, Kraków. 